\title{
PRAKTIK PENGALAMAN LAPANGANDAN DAMPAKNYA TERHADAP KOMPETENSI MAHASISWA PROGRAM STUDI TEKNIK INFORMATIKA DAN KOMPUTER
}

\author{
Ratih Widya Nurcahyo \\ IKIP PGRI Pontianak \\ ratihwidya01@gmail.com \\ Badrun Kartowagiran \\ Universitas Negeri Yogyakarta \\ badrunkw@yahoo.com
}

\begin{abstract}
Abstrak
Penelitian ini di bertujuan untuk mengetahui: (1) kompetensi mahasiswa STKIP PGRI Pontianak dalam kegiatan PPL di SMK, SMA, SMP se Kota Pontianak; (2) pengaruh praktik persekolahan terhadap kompetensi mahasiswa STKIP PGRI Pontianak sebagai calon guru; (3) pengaruh rencana pembelajaran terhadap kompetensi mahasiswa STKIP PGRI Pontianak sebagai calon guru; (4) pengaruh pelaksanaan pembelajaran terhadap kompetensi mahasiswa STKIP PGRI Pontianak sebagai calon guru; (5) pengaruh secara bersama-sama antara praktik persekolahan, rencana pembelajaran, dan pelaksanaan pembelajaran terhadap kompetensi mahasiswa. Hasil penelitian ini menunjukan bahwa (1) kompetensi pedagogik, kepribadian, sosial, termasuk kategori cukup dan kompetensi profesional termasuk kategori baik;(2) terdapat pengaruh positif dan signifikan antara praktek persekolahan terhadap kompetensi mahasiswa sebagai calon guru dengan nilai $R^{2}=0,515$; $p=0,000$; (3) terdapat pengaruh positif dan signifikan antara rencana pembelajaran terhadap kompetensi mahasiswa sebagai calon guru dengan nilai $R^{2}=0,272$; $p=0,000$; (4) terdapat pengaruh positif dan signifikan antara pelaksanaan pembelajaran terhadap kompetensi mahasiswa sebagai calon guru dengan nilai $R^{2}=0,515 ; p=0,000$; dan (5)terdapat pengaruh positif dan signifikan antara praktik persekolahan, rencana pembelajaran, dan pelaksanaan pembelajaran secara bersama-sama terhadap kompetensi mahasiswa sebagai calon guru dengan nilai $R^{2}=0,931$. Prediksi perubahan $Y$ ditunjukan oleh persamaan garis regresi $Y=9,463+0,759 X_{1}+0,819 X_{2}+0,763 X_{3}$.
\end{abstract}

Kata kunci: Kompetensi, Praktik Persekolahan, Rencana Pembelajaran, Pelaksanaan Pembelajaran

\section{FIELD EXPERIENCE PRACTICE AND ITS IMPACT ON STUDENT'S COMPETENCIES PROGRAM INFORMATION AND COMPUTER ENGINEERING}

\begin{abstract}
This research aims to determine: (1) the achievement of student's competence in activities of STKIP PGRI Pontianak Practice Experience (PPL) in vocational, high school, junior high school Pontianak City; (2) the correlation betwen schooling practice and student's competency at STKIP PGRI Pontianak as prospective teachers; (3) correlation betwen the competence of the student and lesson plans STKIP PGRI Pontianak as prospective teachers; (4) correlation betwen student's competence and learning implementation STKIP PGRI Pontianak as prospective teachers; and (5) jointly correlation between schooling practices, lesson plans, and implementation of student's learning and student's competency. These results indicate that (1) pedagogic competence, personality, social, and professional categories each including moderate, moderate, moderate, and good respectively, (2) there is a positive and significant correlation between schooling practices and student's competence with values $R^{2}=0.515 ; p=0.000$; (3) there is a positive and significant correlation between competence lesson plan and student's with a value of $R^{2}=0.272 ; p=0.000$; (4) there is a positive and significant correlation between the implementation of learning with student's competence with
\end{abstract}


a value of $R^{2}=0.515 ; p=0.000$; and (5) there is a positive and significant correlation between schooling practices, lesson plans, and implementation of learning together and the competence of student'ss as prospective teachers with a value of $R^{2}=0.931$. The predicted change in $Y$ is indicated by the regression line equation $Y=9.463+0,759 X 1+0,819 X 2+0,763 X 3$.

Keywords: competence, schooling practices, lesson plans, implementation of learning

\section{PENDAHULUAN}

Peningkatan kualitas pendidikan yang lebih banyak dipengaruhi oleh mutu human resources, dapat dipahami bahwa material resources tidak dapat bermanfaat secara optimal tanpa adanya human resources yang handal. Dengan demikian dapat dikatakan bahwa keberhasilan pendidikan ditentukan oleh sumber daya manusia yang profesional, berkualitas, dan mempunyai komitmen yang tinggi dalam bidang pendidikan. Guru dipandang sebagai faktor kunci keberhasilan pendidikan, karena gurulah yang berinteraksi secara langsung dengan peserta didik dalam kegiatan pembelajaran di sekolah. Kualitas guru dipandang sebagai kualitas lulusan/output pendidikan, sehingga kurang meningkatnya mutu pendidikan sebagaimana sering diberitakan selama ini hampir selalu dihubungkan dengan rendahnya kualitas guru.

Guru sebagai pendidik melakukan rekayasa pembelajaran. Rekayasa pembelajaran tersebut dilakukan berdasarkan kurukulum yang berlaku (Dimyati dan Mudjiono, 2006, p.3). Dalam setiap usaha peningkatkan mutu pendidikan mutu pendidikan seperti pembaharuan kurikulum, pengembangan metode pembelajaran, penyediaan sarana dan prasarana pendidikan, maupun pengembangan evaluasi hasil belajar, hanya akan berarti apabila melibatkan guru sebagai ujung tombak pelaksanaan pendidikan di lapangan. Oleh karena itu upaya peningkatan mutu pendidikan secara luas tidak dapat dilepaskan dari eksistensi seorang guru sebagai pendidik profesional disekolah. Termasuk didalamnya menguasai langkah-langkah penelitian dan kajian kritis dan nambah wawasan dan memperdalam pengetahuan bidang studi yang diajarkan.

Hartoyo (1999, p.3) mengungkapkan bahwa sebagian guru kurang memiliki kemampuan untuk menerapkan produk inovasi pendidikan, rendahnya kemampuan guru kemampuan guru dengan menguasai bidang studi, kurang menguasai teknik dan metodologi pembelajaran yang sesuai dengan karakteristik materi pembelajaran.

Dengan besarnya tuntutan kualitas pendidikan yang terus berkembang, maka penelitian tentang pelaksanaan PPL mahasiswa Prodi TIK STKIP PGRI Pontianak sangat diperlukan untuk mengungkapkan seberapa besar tingkat ketercapaian kompetensi mahasiswa sebagai calon guru. Dalam standar kompetensi guru pemula tersebut memiliki empat rumpun kompetensi yaitu; Kompetensi Pedagogik, Kompetensi Kepribadian, Kompetensi Sosial dan Kompetensi Profesional.

Oleh karenanya, tahapan evaluasi ketercapaian standar kompetensi ini sangat penting dan segera dilakukan untuk mengungkapkan selengkap mungkin terhadap prestasi mahasiswa PPL dalam hubungannya dengan pembinaan mahasiswa Prodi TIK STKIP PGRI Pontianak sebagai calon guru yang profesional.

Kegiatan PPL dilaksanakan selama 1 (satu) semester pada semester 7 selama kegiatan PPL berlangsung setiap mahasiswa akan di dampingi oleh seorang guru pamong dari sekolah tempat mereka melaksanakan kegiatan PPL.

Setelah kegiatan PPL selesai dilaksanakan setiap guru pomong mempunyai kewajiban unuk melakukan penilaian terhadap mahasiswa selama kegiatan kegiatan PPL berlangsung. Adapun bentuk penilaian yang diberikan berupa penilaian rencana pembelajaran dan penilaian terhadap pelaksanaan pembelajaran yang dapat dilihat pada lampiran.

\section{Program PPL STKIP PGRI Pontianak}

Program Pengalaman Lapangan (PPL) lembaga pendidikan keguruan atau ilmu pendidikan di STKIP PGRI Pontianak merupakan salah satu kegiatan Program Akademik yang wajib ditempuh. Program Pengalaman Lapangan ini mempunyai nilai 
yang sama dengan kedudukan mata kuliah lainnya pada setiap jurusan atau bidang studi. Profesi guru merupakan pekerjaan yang mulia kalau dibandingkan dengan pekerjaan lainnya sebab melalui gurulah setiap orang mendapatkan ilmu pengetahuan, namun pekerjaan ini pun mempunyai beban yang cukup berat, sebab guru akan turut mempengaruhi perkembangan pengetahuan masyarakat seperti baik buruknya perilaku pelajar. Faktor guru sangat mempengaruhi dalam membentukannya walaupun bukan satusatunya faktor penentu. Masih banyak faktor lainnya yang mempengaruhi seperti keluarga, lingkungan sekitar dan lain sebagainya

STKIP PGRI Pontianak adalah salah satu lembaga pendidikan yang mempersiapkan mahasiswa sebagai calon guru. STKIP PGRI Pontianak senantiasa berusaha untuk meningkatkan mutu pendidikan agar setiap lulusannya memiliki profesionalisme dalam ilmu pendidikan teknik informatika dan komputer baik secara teori maupun praktek. STKIP PGRI Pontianak mengharapkan lulusannya memiliki pribadi yang baik sesuai dengan tujuan Pendidikan Nasional yaitu dengan meningkatkan kecerdasan dan keterampilan, memelihara budi pekerti, mempertebal semangat kebangsaan agar dapat menumbuhkan manusia pembangunan yang dapat membangun dirinya sendiri serta dapat bersama-sama bertanggung jawab atas kelangsungan hidup bangsanya.

Langkah-langkah yang diambil STKIP PGRI Pontianak dalam mencapai tujuan tersebut adalah mewajibkan kepada setiap mahasiswa untuk melakukan Praktek Pengalaman Lapangan (PPL). Melalui kegiatan ini diharapkan setiap mahasiswa dapat mengambil pelajaran dan hikmah positif dan menjadikannya sebagai bekal ilmu dan dapat menyampaikan ilmu pengetahuan dengan lebih baik lagi dan tercapainya suatu keberhasilan yang dapat dibanggakan.

\section{Misi dari Praktik Pengalaman Lapangan (PPL) STKIP PGRI Pontianak}

Penyiapan dan menghasilkan guru atau tenaga kependidikan yang memiliki nilai, sikap, pengetahuan, dan keterampilan profesional.
Pengintegrasian dan pengimplementasian ilmu yang telah dikuasainya ke dalam praktik keguruan dan atau praktik kependidikan

Selanjutnya ditambahkan bahwa Tujuan dari PPL STKIP PGRI Pontianak antara lain: (a)Memberikan pengalaman kepada mahasiswa dalam bidang pembelajaran dan manajerial di sekolah atau lembaga, dalam rangka melatih dan mengembangkan kompetensi keguruan atau kependidikan. (b) Memberikan kesempatan kepada mahasiswa untuk mengenal, mempelajari, dan menghayati permasalahan sekolah atau lembaga baik yang terkait dengan proses pembelajaran maupun kegiatan manajerial kelembagaan. (c)Meningkatkan kemampuan mahasiswa untuk menerapkan ilmu pengetahuan dan keterampilan yang telah dikuasai secara interdisipliner ke dalam kehidupan nyata di sekolah atau lembaga pendidikan.(d) Memberikan kesempatan untuk memperoleh pengalaman yang nyata dalam menerapkan teori kegiatan belajar mengajar yang diperoleh selama menempuh pendidikan.(e)Melalui kegiatan PPL, mahasiswa mampu memahami situasi mengajar yang sesungguhnya sehingga mampu mendidik dengan metode yang tepat dan mampu menanamkan nilai-nilai moral pada peserta didik serta mampu mengatasi kesulitan di kelas pada waktu mengajar.(f)Memberi bekal dan mempersiapkan mahasiswa sebagai calon guru ahli agar siap pakai dan dapat melaksanakan tugasnya di lapangan apabila lulus nanti.(g)Mempersiapkan mahasiswa untuk mengembangkan kemampuan agar terampil dan profesional apabila benar-benar menjadi seorang guru.

Dari misi dan tujuan PPL STKIP PGRI Pontianak tersebut diatas menunjukkan bahwa Institusi STKIP PGRI Pontianak sabagai perguruan tinggi swasta tetap memiliki komitmen yang besar untuk mencetak lulusan mahasiswanya sebagai calon guru yang berkualitas dan diharapkan memiliki kompetensi sebagai calon guru pemula yang profesional.

\section{Pelatihan Keterampilan Mengajar Terbimbing}

Pelatihan keterampilan mengajar terbimbing yaitu turun langsung ke lapangan 
mengelola kelas dibimbing oleh seorang tenaga staf guru (guru pamong) yang bersangkutan, biasanya dimulai dengan membuka dan menutup materi, menyampaikan materi, penulis mendapatkan bimbingan secara langsung dari guru pamong. Semua perangkat persiapan mengajar ini termuat dalam Program Tahunan, Program Semester dan lebih jelasnya dijabarkan dalam rencana Pelaksanaan Pembelajaran (RPP) yang secara sistematis tersusun demi lancarnya kegiatan belajar mengajar.

\section{Pelatihan Keterampilan Mengajar Mandiri}

Pelatihan keterampilan mengajar mandiri sama dengan yang terbimbing. Namun dalam hal ini lebih memfokuskan pada kemampuan seorang calon guru didalam pengelolaan kelas dan melakukan kegiatan belajar mengajar secara mandiri. Setelah dianggap mampu, calon guru diperbolehkan untuk melakukan kegiatan belajar mengajar secara mandiri seperti halnya dengan guru lainnya sebelum mengajar agar mempersiapkan tugas-tugas keguruan lainnya.

Dalam PPL ini, mahasiswa mendapatkan pengalaman pelatihan tugas-tugas keguruan secara terbimbing dan mandiri. Dalam tugas keguruan terbimbing ini mahasiswa mendapatkan bimbingan dari guru pamong dan dosen pembimbing. Sedangkan dalam tugas-tugas keguruan mandiri, mahasiswa mendapatkan pengalaman dari kegiatan mengajar didalam kelas yang berlangsung selama mahasiswa melaksanakan PPL dalam waktu 1 semester.

\section{Praktik Persekolahan}

Praktik persekolahan merupakan tugastugas yang dilakukan mahasiswa selain praktik mengajar seperti membuat program tahunan dan semester, melaksanakan administrasi sekolah, melaksanakan piket, mengawasi dan membimbing siswa dalam kegiatan ekstrakulikuler, merencanakan pembelajaran.

\section{Rencana Pembelajaran}

Perencanaan Pembelajaran terdiri dari dua kata yaitu Perencanaan berasal dari kata rencana yang artinya pengambilan keputusan tentang apa yang harus dilaksanakan untuk mencapai tujuan. Perencanaan pengajaran berarti pemikiran tentang penerapan prinsipprinsip umum mengajar didalam pelaksanaan tugas mengajar dalam suatu interaksi pengajaran tertentu yang khusus baik yang berlangsung didalam kelas atau diluar kelas.

\section{Pelaksanaan Pembelajaran}

Pelaksanaan proses pembelajaran terdiri dari 3 (tiga) tahapan yaitu: Kegiatan pendahuluan, Kegiatan inti dan Penutup.

\section{Tugas dan Peran Guru Dalam Proses Pem- belajaran}

Tugas dan peranan guru dalam proses pembelajaran pendidikan kejuruan diarahkan, untuk membentuk kemampuan siswa di dalam mengembangkan perolehan belajarnya baik pada aspek pengetahuan, keterampilan dan nilai, maupun pada aspek sikap, juga guna menunjang pengembangan profesinya (Depdikbud, 1995). Tugas dan peran guru tidak terlepas dari proses pembelajaran dan hasil pembelajaran berbasis kompetensi. Pada aspek sistem pembelajaran bagaimana tugas guru selain harus mampu menerapkan proses pembelajaran yang sesuai dengan model-model pembelajaran, penyampaian dan mengatur pembelajaran, pembelajaran yang fleksibel, penggunaan sumber-sumber teknologi dan pengembangannya. Guru juga dituntut mampu membantu proses pembelajaran berlangsung sebagai fasilitator dan pembimbing yang profesional. Dalam sistem pembelajaran berbasis kompetensi, guru dituntut mampu mengubah standar kompetensi kedalam hasil pembelajaran yang direncanakan. Sebagaimana Roger, Hugh, dan Barry, (1995, p.228), menyatakan:

From this informaton, we can begin to develop learning outcomes. These define what a leaner is expected to demonstrate on copletion of a modul. They need to be specific, measurable, achievable, relevant and trackable.

Dengan demikian guru dapat mengukur keberhasilan siswa menurut kriteria kompetensi yang ditetapkan dalam program belajar mengajar. 


\section{Kemampuan Mengajar Guru}

Hakekat mengajar adalah kegiatan belajar yang membantu siswa memperoleh informasi, ide, keterampilan, nilai-nilai, cara berpikir, sarana untuk mengekspresikan dirinya, dan juga cara-cara belajar. Menurut Joyce dan Weil $(1996,7)$ "Models of teaching are really models of learning. As we help students acquire information, ideas, skills, values, ways of thinking, and means of expressing them selves, we are also teaching them how to learn". Pengertian mengajar tersebut secara implisit berarti upaya mengorganisasikan dan mengatur lingkungan belajar untuk mendorong, menumbuhkan, dan membantu siswa melakukan kegiatan belajar dalam mengembangkan dirinya secara optimal.

\section{Kompetensi Guru}

Kata kompetensi berasal dari bahasa Inggris "Competency" yang berarti "ability, capability, proficiency, qualification, eligibility, skill, dan adequacy" yang artinya kemampuan, kesanggupan, keahlian, kecakapan, memenuhi syarat, kepandaian dan kemahiran. Menurut Kamus Besar Bahasa Indonesia kompetensi adalah kewenangan (kekuasaan) untuk menentukan (memutuskan) sesuatu.

Roe (2001, p.95) mengemukakan definisi kompetensi sebagai berikut :

"Competence in defined as the ability to adequately perform a task duty or role. Competence intergrates knowledge, skill, personal values and attitudes. Competence builds on knowledge and skills ad is acquired through work experience and learning by doing".

Definisi tersebut menjelaskan bahwa kompetensi merupakan kemempuan untuk melaksanakan satu tugas, peran atau tugas, kemampuan mengintegrasikan pengetahuan, keterampilan-keterampilan, sikap-sikap dan nilai-nilai pribadi, dan kemampuan untuk membangun pengetahuan dan keterampilan yang didasarkan pada pengalaman dan pembelajaran yang dilakukan.

Barnazette (2005, p.14) menjemaskan pengertian kompetensi sebagai berikut :

Competencies are based on what a person does; they are behavior and observable.
If one is competent, then the result is effective or possibly outstanding job performance. A set of competencies is referred to as a competency model and is a collection of behaviors supported by underlying knowledge, skills, and attitides thet related to a specific role or job responsibility.

Kompetensi didasarkan pada pekerjaan seseorang, mereka berperilaku dan bisa diamati. Jika seseorang memiliki kompetensi, maka hasilnya akan efektif atau dimungkinkan akan berhasil kinerjanya dalam pekerjaan. Satu set kompetensi merupakan model kompetensi dan merupakan kumpulan dari tingkah laku yang didukung berdasarkan pada pengetahuan, keterampilan, dan sikap yang berhubungan dengan peran tertentu atau tanggung jawab pekerjaan.

Menurut Wibowo (2007, p.324) Kompetensi adalah karakteristik pengetahuan da keterampilan yang dimiliki dan dibutuhkan oleh setiapn individuyang memampukan mereka untuk melakukan tugas dan tanggung jawab mereka secara efektif dan meningkatkan standar kualitas peofesional dalam pekerjaan mereka.

\section{Kompetensi Pedagogik}

Ilmu pendidikan sebagai bekal guru dalam mengajar diperoleh melalui jenjang pendidikan yang lebih tinggi yakni tingkat sarjana (S-1). Di dalam program bidang studi berhak membicarakan bidang studi dalam pendidikan. Meskipun demikian, setiap lulusan sarjana pendidikan sebaiknya belum diangkat menjadi guru tetap. Guru yang memiliki sarjana pendidikan dapat sikatakna telah menguasai pengetahuan tentang bidang ilmu keguruan. Namun pada kenyataan, masih banyak guru yang terlalu teoritis yakni belum mampu bertindak sebagai seorang guru yang profesional. Sehubungan dengan itu, pada awal tahun guru bekerja, lebih baik diberi status calon guru atau guru bantu. Hal ini berkaitan dengan sertifikasi yang diberikan kepada setiap guru untuk menyatakan seorang guru layak atau tidak layak mengajar. Menurut Djohar (2006, p.131) sertifikasi ini diberikan oleh Lembaga Pendidikan Tenaga Keguruan (LPTK) yang terakreditasi. 


\section{Kompetensi Kepribadian}

Kompetensi kepribadian menunjukan kuaitas kemampuan pribadi guru yang diperlukan agar dapat menjadi guru yang baik. Menurut undang-undang Guru 2005, kompetensi kepribadian yang harus dimiliki seorang guru berkaitan dengan pemahaman diri, penerimaan diri, pengarahan diri, dan perwujudan diri. Kompetensi kepribadian lainnya mencakup kepribadian yang utuh, berbudi luhur, jujur, dewasa, beriman, dan bermoral. Kompetensi kepribadiain lebih menunjuk pada jati diri guru sebagai pribadi yang baik, bertanggung jawab, terbuka, dan termotivasi untuk selalu maju. Usman (2002, p.16) mengungkapkan bahwa kompetensi pribadi meliputi lima hal yaitu: (a) mengembangkan kepribadian; (b) berinteraksi dan berkomunikasi; (c) melaksanakan bimbingan dan penyuluhan; (d) melaksanakan administrasi sekolah; (e) melaksanakan penelitian sederhana untuk keperluajn pengajaran.

McLeod dalam Muhabbinsyah (2010, p.224) mengartikan "kepribadian (personality) sebagai sifat khas yang dimiliki seseorang." Dalam hal ini, kata lain yang dekat artinya dengan kepribadian adalah karakter atau identitas. Guru sebagai tenaga pendidik yang tugas utamanya mengajar, memiliki karakteristik kepribadian yang sangat berpengaruh terhadap keberhasilan pengembangan sumber daya manusia. Kepribadian yang mantap dari sosok seorang guru akan memberikan teladan yang baik terhadap anak didik maupun masyarakatnya, sehingga guru akan tampil sebagai sosok yang patut "digugu" (ditaati nasehat/ ucapan/ perintahnya) dan "ditiru" (di contoh sikap dan perilakunya). Kepribadian guru merupkan faktor terpenting bagi keberhasilan belajar anak didik. Dalam kaitan ini, Darajat dalam Muhabbinsyah (2010, p.225) menegaskan bahwa, kepribadian itulah yang akan menentukan apakah ia akan menjadi pendidik dan pembina yang baik bagi anak didiknya, ataukah akan menjadi perusak atau penghancur bagi masa depan anak didiknya terutamabagi anak didik yang masih kecil (tingkat dasar) dan mereka yang sedang mengalami kegoncangan jiwa (tingkat menengah).
Karakteristik kepribadian yang berkaitan dengan keberhasilan guru dalam menggeluti profesinya adalah meliputi fleksibilitas kognitif dan keterbukaan psikologis. Fleksibilitas kognitif atau keluwesan ranah cipta merupakan kemampuan berfikir yang diikuti dengan tindakan secara simultan dan memadai dalam situasi tertentu. Guru yang fleksibel pada umumnya ditandai dengan adanya keterbukaan berpikir dan beradaptasi. Selian itu, ia memiliki resistensi atau daya tahan terhadap ketertutupan ranah cipta yang prematur dalam pengamaatn dan pengenalan.

\section{Kompetensi Sosial}

Guru yang efektif adalah guru yang mampu membawa siswanya dengan berhasil mencapai tujuan pengajaran. Mengajar di depan kelas merupakan perwujudan interaksi dalam pproses kompunikasi. Peraturan Pemerintah No. 19 Tahun 2005 tentang Standar Nasional Pendidikan, penjelasan Pasal 18 ayat (3) butir d bahwa kompetensi sosial adalah "kemampuan pendidik sebagai bagian dari masyarakat untuk berkomunikasi dan bergaul secara efektif dengan peserta didik, sesama pendidik, tenaga kependidikan, orangtua/wali peserta dididk, dan masyarakat sekitar."

Kompetensi sosial guru memegang peranan penting, karena sebagai pribadi yang hidup di tengah-tengah masyarakat, guru juga perlu memiliki kemampuan untuk berbaur dengan masyarakat. Jika di sekolah guru diamati dan dinilai oleh peserta didik, teman sejawat, dan atasannya, maka di masyarakat dinilai dan diawasi oleh masyarakat.

Admiraal et.al (2007, pp.63-64) menyatakan:

Although definitions of social competence vary, there seems to beconsensus that it involves the ability ti intergrate cagnitive, emotional and behavioural realms in order to: (a)Establish, maintain and develop constructive social relationships;(b)Manage interpersonal difficulties and refrain from harming oneself and other;(c)Contribute collaboratively and constructively to peers, students, schools and the wider community. 
(Meskipun definisi kompetensi sosial bervariasi, tampaknya ada konsensus yang melibatkan kemampuan untuk mengintegrasikan kognitif, emosional dan perilaku untuk: (a) Membangun, memelihara dan mengembangkan hubungan sosial yang konstruktif; (b) Mengelola kesulitan interpersonal dan menahan diri dari merugukan diri sendiri dn orang lain. (c) Berkontribusi kolaboratif dan konstruktif teman sebaya, siswa sekolah dan masyarakat yang lebih luas).

\section{Kompetensi Profesional}

Kompetensi profesional ini mensyaratkan kualifikasi akademik guru yakni lulusan sarjana (S-1) bidang pendidikan. Hal itu sesuai dengan harapan bahwa guru lulusan sarjana dituntut memiliki kompetensi lebih baik dibanding guru yang memiliki pendidikan lebih rendah. Menurut Suparno, dkk $(2002 ; 52)$ pentingnya guru SD lulusan sarjana (S-1) pendidikan terkait dengan penyiapan guru yang otonom dengan daya kreativitas yang tinggi dalam mengelola pembelajaran, inovatif dalaam bidangnya dan bidang lain, serta tidak hanya puas bila sudah mengerjakan (menyelesaikan) bahan. Guru yang otonom adalah guru yang juga sebagai pemikir dan perancang bahan pelajaran yang kritis dan analisis serta berani memilih dan mengambil keputusan yang paling baik bagi anak didiknya.

Wawasan yang luas dan berbagai ciri yang melekat dan terinternalisasi dalam lulusan sarjana (S-1) akan memberikan pengaruh pada proses pendampingan siswa dalam belajar. Hal ini dapat membantu siswa untuk memiliki wawasan luas, kreatif, dan kritis. Untuk menjadi guru otonom, penguasaan baik ilmu pengetahuan maupun cara pembelajarannya menjadi sangat penting. Untuk itu, idealnya guru memiliki tingkat pendidikan sarjana (S-1).

Tamyong (1987) dalam Usman (2009, p.15) menyatakan bahwa "guru profesional adalah orang yang terdidik dan terlatih dengan baik, serta memiliki pengalaman yang kaya di bidangnya." Yang dimaksud terdidiki dan terlatih bukan hanya memperoleh pendidikan formal tetapi juga harus menguasai berbagai strategi atau teknik di dalam kegiatan belajar mengajar serta menguasai landasan-landasan kependidikan.
Usman (2009, p.17) membagi kompetensi profesional menjadi lima bagian, "(1) Menguasai landasan pendidikan, (2) Menguasai bahan pengajaran, (3) Menyusun program penhajaran, (4) Melaksanakan program pengajaran, (5) Mmenilai hasil dari proses belajar mengajar yang telah dilaksanakan."

\section{Kerangka Berpikir}

Dalam penelitian ini, variabel praktik persekolahan, rencaan pembelajaran dan pelaksanaan pembelajaran sebagai variabel bebas. Ketiga varibel tersebut diduga mempengaruhi kompetensi mahasiswa sebagai variabel terikat baik secara langsung maupun tidak langsung. Pengaruh ketiga varibel bebas terhadap varibel terikat dapat digambarkan sebagai berikut :

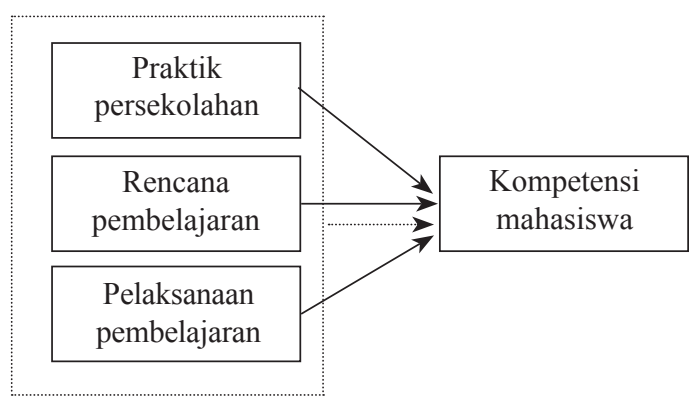

Gambar 1. Kerangka Berpikir

\section{METODE PENELITIAN}

\section{Jenis Penelitian}

Jenis penelitian ini termasuk jenis penelitian ex post facto (non eksperimenn) yaitu penelitian empiris dimana peneliti tidak mengendalikan variabel bebas secara langsung karena variable tersebut sudah terjadi (Furchan 2011, p.443).

Berdasarkan tingkatnya penelitian ini tergolong pada jenis penelitian deskritif kuantitatif dan metode explanatory, yaitu metode yang menjelaskan variable-variabel yang diteliti serta hubungan antara satu variable dengan variable lain. Dimana penelitian yang dilakukan untuk menggumpulkan fakta-fakta berdasarkan pengukuran terhadap gejala yang terjadi pada diri responden tidak melakukan perlakuan-perlakuan maupun manipulasimanipulasi 
terhadap variable penelitiannya (Creswell 2010, p.316).

\section{Tempat dan Waktu Penelitian}

Penelitian ini dilakukan di STKIP PGRI Pontianak, SMA, SMK dan SMP se Kota Pontianak, tempat mahasiswa STKIP PGRI Pontianak sedang melakukan tugas praktik mengajar, dalam program Praktik Pengalaman Lapangan (PPL). Mahasiswa praktik mengajar di SMA, SMK dan SMP baik di sekolah negeri dan swasta yang tersebar di tiap-tiap kecamatan di Kota Pontianak. Penelitian dilakukan pada bulan Februari 2014 sampai dengan bulan Mei tahun 2014.

\section{Populasi dan Sampel Penelitian}

Populasi penelitian ini adalah seluruh mahasiswa STKIP PGRI Pontianak prodi TIK yang mengikuti Praktik Pengalaman Lapangan (PPL) pada seluruh SMA, SMK dan SMP se Kota Pontianak pada tahun 2013, berjumlah 140 orang mahasiswa tersebar di 72 Sekolah di Kota Pontianak.

Pengambilan sampel penelitian dilakukan dengan menggunakan teknik Porpotional random sampling. Penentuan ukuran sampel menggunakan tabel Krejcie \& Morgan, berdasarkan tabel tersebut ditetapkan sampel penelitian sebanyak 102 mahasiswa STKIP PGRI Pontianak prodi Teknologi Informasi dan Komputer (TIK) yang mengikuti kegiatan PPL STKIP PGRI Pontianak di SMA, SMK dan SMP se Kota Pontianak.

\section{Teknik Pengumpulan Data dan Instrumen Penelitian}

Teknik pengumpulan data penelitian menggunakan angket tertulis/ kuesioner untuk mengumpulkan data identitas siswa dengan cara membagikan angket berisi butirbutir pertanyaan atau pernyataan instrumen penelitian tehadap responden, yang diperlukan dari semua variabel yang diteliti.

Pemberianskoruntuksetiap butirinstrumen menggunakan skala Likert (Suryabrata, 1999, p.264).Ada dua jenis pertanyaan/ pernyataan pada penelitian ini yaitu pernyataan positif/ mendukung dan pernyataan negatif/tidak mendukung.

\section{Teknik Analisis Data}

Analisis data adalah proses pengolahan data penelitian. Analisis data yang digunakan pada penelitian ini, yaitu statistik deskriptif, dan statistik inferensial. Analisis deskriptif ditabulasikan dengan mengetahui nilai maksimun, nilai minimum, nilai rerata(mean), nilai tengah (median), nilai yang Paling sering muncul (modus), standar deviasi, varians, dan range nilai pada masing-masing variabel, baik variabel dependen maupun variabel independen.

\section{Uji Analisis Data}

Uji persyaratan analisis dimaksud untuk mengetahui apakah data yang dikumpulkan telah memenuhi syarat untuk dianalisis dengan teknik analisis yang yang direncanakan. Hal ini dilakukan agar dalam analisis selanjutnya tidak mengalami hambatan dan sesuai dengan teknik analisis yang direncanakan. Untuk teknik analisis regresi ganda memerlukan beberapa syarat, yakni variabel terikat mengikuti sebaran normal baku, variabel bebas dan variabel terikat memiliki korelasi linier, dan antara sesama variabel bebas korelasinya tidak terlalu tinggi.

\section{HASIL PENELITIAN}

Penelitian yang telah diselesaikan, selanjutnya dihitung dan analisis untuk menjawab hipotesis penelitian. Perhitungan penelitian menggunakan analisis deskriptif untuk mengetahui gambaran dari variabel penelitian, dan analisis inferensial untuk mengetahui besarnya pengaruh dari tiap-tiap variabel penelitian.

\section{Analisis Deskriptif}

Berikut gambaran umum pencapaian kompetensi mahasiswa STKIP PGRI Pontianak dalam kegiatan PPL ditinjau dari Kompetensi Pedagogik, Kompetensi Kepribadian, Kompetensi Sosial Dan Kompetensi Profesional.

\section{Kompetensi Pedagogik}

Berdasarkan penelitian yang dilakukan pada mahasiswa prodi TIK yang melaksanakan PPL didapatkan hasil bahwa kompetensi pedagogik yang memiliki kecendrungan 
kategori kategori baik sebesar 38,2\%, yang memiliki kecendrungan kategori cukup sebesar 51,0\%, yang memiliki kecendrungan kategori kurang sebesar 9,8\% , yang memiliki kecendrungan kategori sangat kurang sebesar $1,0 \%$. Hal ini menunjukan bahwa kompetensi pedagogik mahasiswa prodi TIK yang melakukan PPL termasuk dalam kategori cukup. Berdasarkan jawaban tersebut diperoleh hasil analisis nilai minimum di peroleh sebesar 1,44, maksimal sebesar 4,00, rerata (Mean) sebesar 3,30, median sebesar 3.22, modus sebesar 3,00a dan standar deviasi sebesar 0,532.

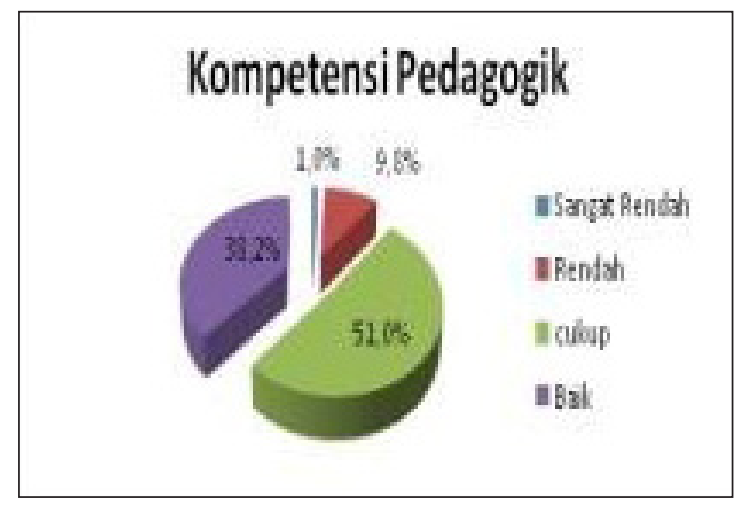

Gambar 2. Diagram Pie Distribusi Kompetensi Pedagogik

\section{Kompetensi Kepribadian}

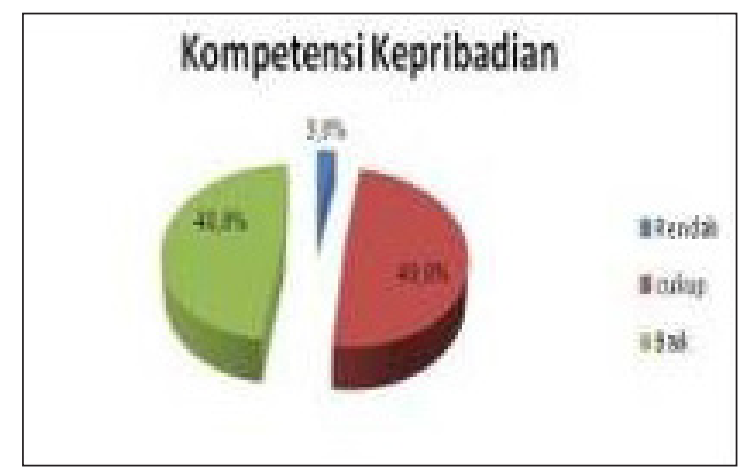

Gambar 3. Diagram Pie Distribusi

Kompetensi Kepribadian

Berdasarkan penelitian yang dilakukan pada mahasiswa prodi TIK yang melaksanakan PPL didapatkan hasil bahwa kompetensi kepribadian yang memiliki kecendrungan kategori kategori baik sebesar 48,0\%, yang memiliki kecendrungan kategori cukup sebesar 49,0\%, yang memiliki kecendrungan kategori kurang sebesar 3,0\%. Hal ini menunjukan bahwa kompetensi pedagogik mahasiswa prodi TIK yang melakukan PPL termasuk dalam kategori cukup. Berdasarkan jawaban tersebut diperoleh hasil analisis nilai minimum di peroleh sebesar 2,29, maksimal sebesar 4,00, mean sebesar 3,36, median sebesar 3,29, modus sebesar 3,14 dan standar deviasi sebesar 0,389 .

\section{Kompetensi Sosial}

Berdasarkan penelitian yang dilakukan pada mahasiswa prodi TIK yang melaksanakan PPL didapatkan hasil bahwa kompetensi sosial yang memiliki kecendrungan kategori kategori baik sebesar $44,1 \%$, yang memiliki kecendrungan kategori cukup sebesar 55,9\%, yang memiliki kecendrungan kategori kurang sebesar 2,0\%. Hal ini menunjukan bahwa kompetensi pedagogik mahasiswa prodi TIK yang melakukan PPL termasuk dalam kategori cukup. Berdasarkan jawaban tersebut diperoleh hasil analisis nilai minimum di peroleh sebesar 2,50, maksimal sebesar 4,00, mean sebesar 3,40 , median sebesar 3,38, modus sebesar 3,00 dan standar deviasi sebesar 0,387.

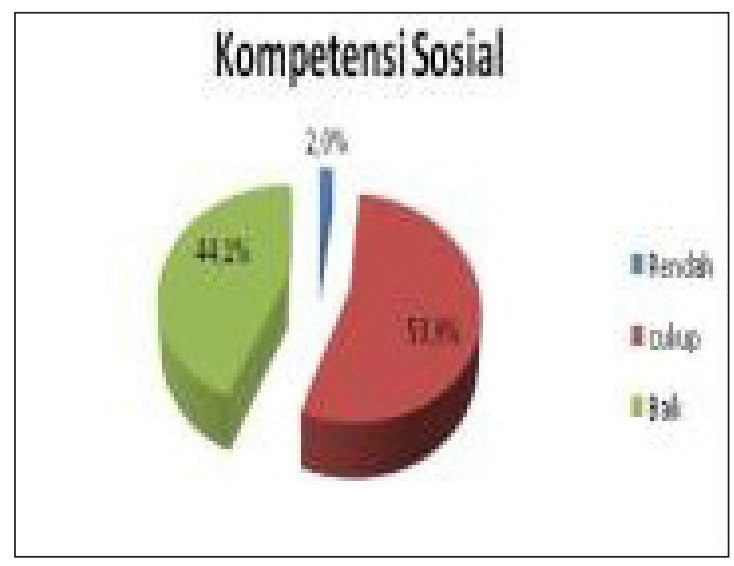

Gambar 4. Diagram Pie Distribusi Kompetensi Sosial

\section{Kompetensi Profesional}

Berdasarkan penelitian yang dilakukan pada mahasiswa prodi TIK yang melaksanakan PPL didapatkan hasil bahwa kompetensi profesional yang memiliki kecendrungan kategori kategori baik sebesar $51,0 \%$, yang memiliki kecendrungan kategori cukup sebesar 49,0. Hal ini menunjukan bahwa kompetensi pedagogik mahasiswa prodi TIK yang melakukan PPL termasuk dalam kategori baik. Berdasarkan jawaban tersebut diperoleh hasil 
analisis nilai minimum di peroleh sebesar 2,71, maksimal sebesar 4,00, mean sebesar 3,42, median sebesar 3,43, modus sebesar 3,00 dan standar deviasi sebesar 0,389.

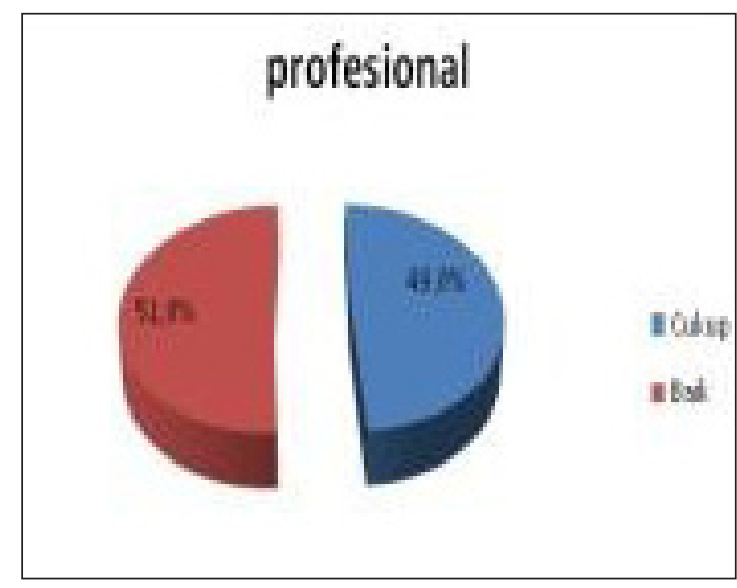

Gambar 5. Diagram Pie Distribusi Kompetensi Profesional

\section{Pengujian Hipotesis}

Untuk mengetahui praktik persekolahan terhadap kompetensi mahasiswa digunakan analisis regresi linear sederhana. Berikut ini adalah hasil analisis linear sederhana untuk pengaruh praktik persekolahan $\left(\mathrm{X}_{1}\right)$ terhadap kompetensi mahasiswa (Y). Untuk mengukur besarnya sumbangan variabel praktik persekolahan terhadap variasi naik turunya variabel kompetensi mahasiswa. Koefisien pengaruh antara praktik persekolahan terhadap kompetensi mahasiswa sebesar 0,717 yang artinya terdapat hubungan antara aktivitas persekolahan terhadap kompetensi mahasiswa. Koefisien Determinasi $\left(\mathrm{R}^{2}\right)=0,515$ atau 51,5\% yang artinya praktik persekolahan memberikan pengaruh sebesar $51,5 \%$ terhadap kompetensi mahasiswa sedangkan $48,5 \%$ dipengaruhi variabel lain yang tidak diteliti.

Untuk mengetahui rencana pembelajaran terhadap kompetensi mahasiswa digunakan analisis regresi linear sederhana. Berikut ini adalah hasil analisis linear sederhana untuk pengaruh pelaksanaan pembelajaran $\left(\mathrm{X}_{2}\right)$ terhadap kompetensi mahasiswa $(\mathrm{Y})$. Untuk mengukur besarnya sumbangan variabel rencana pembelajaran terhadap variasi naik turunya variabel kompetensi mahasiswa. Koefisien pengaruh antara rencana pembelajaran terhadap kompetensi mahasiswa sebesar 0,522 yang artinya terdapat hubungan antara rencana pembelajarn terhadap kompetensi mahasiswa. Koefisien Determinasi $\left(\mathrm{R}^{2}\right)=0,272$ atau $27,2 \%$ yang artinya rencana pembelajaran memberikan pengaruh sebesar $27,2 \%$ terhadap kompetensi mahasiswa sedangkan $72,8 \%$ dipengaruhi variabel lain yang tidak diteliti.

Untuk mengetahui pelaksanaan terhadap kompetensi mahasiswa digunakan analisis regresi linear sederhana. Berikut ini adalah hasil analisis linear sederhana untuk pengaruh pelaksanaan pembelajaran $\left(\mathrm{X}_{3}\right)$ terhadap kompetensi mahasiswa (Y). Untuk mengukur besarnya sumbangan variabel pelaksanaan pembelajaran terhadap variasi naik turunya variabel kompetensi mahasiswa. Koefisien pengaruh antara pelaksanaan pembelajaran terhadap kompetensi mahasiswa sebesar 0,718 yang artinya terdapat hubungan antara pelaksanaan pembelajaran terhadap kompetensi mahasiswa. Koefisien Determinasi $\left(\mathrm{R}^{2}\right)=$ $0,515 \mathrm{atau} 51,5 \%$ yang artinya pelaksanaan pembelajaran memberikan pengaruh sebesar $51,5 \%$ terhadap kompetensi mahasiswa sedangkan $48,5 \%$ dipengaruhi variabel lain yang tidak diteliti.

\section{Regresi Linier Berganda}

Analisis regresi linier berganda digunakan untuk mengetahui Pengaruh Praktik persekolahan, Rencana Pembelajaran dan Pelaksanaan Pembelajaran terhadap Kompetensi Mahasiswa STKIP PGRI Pontianak sebagai calon guru.

Hasil analisis regresi linier berganda tersebut dimasukkan ke dalam persamaan menjadi:

$$
Y=9,463+0,759 X_{1}+0,819 X_{2}+0,763 X_{3}
$$

Kompetensi Mahasiswa $=9,463+$ 0,759 Praktik persekolahan $+0,819$ Rencana Pembelajaran $+0,763$ Pelaksanakan Pembelajaran Bentuk persamaan tersebut diartikan sebagai berikut: Nilai konstanta sebesar 9,463 menunjukan bahwa jika tidak ada variabel praktik persekolahan $\left(\mathrm{X}_{1}\right)$, rencana pembelajaran $\left(X_{2}\right)$, pelaksanaan pembelajaran $\left(\mathrm{X}_{3}\right)$ maka skor kompetensi mahasiswa $(\mathrm{Y})$ adalah sebesar 9,463. Koefisien regresi (b1) 
adalah sebesar 0,759 menunjukan bahwa setiap penambahan satu skor praktik persekolahan (X) maka akan meningkatkan kompetensi mahasiswa sebesar 9,463 dengan asumsi bahwa variabel rencana pembelajarandan pelaksanaan pembelajaran dari model regresi adalah tetap, koefisien regresi (b2) sebesar 0,819 menunjukan bahwa setiap penambahan satu skor rencana pembelajaran $\left(\mathrm{X}_{2}\right)$ maka akan meningkatkan kompetensi mahasiswa (Y) sebesar 9,463 dengan asumsi bahwa variabel praktik persekolahan dan pelaksanaan pembelajaran dari model regersi adalah tetap, koefisien regresi (b3) sebesar 0,763 menunjukan bahwa setiap penambahan satu skor pelaksanaan pembelajaran $\left(\mathrm{X}_{3}\right)$ maka akan meningkatkan kompetensi mahasiswa (Y) sebesar 9,463 dengan asumsi bahwa variabel praktik persekolahan dan rencana pembelajarandari model regresi adalah tetap.

Untuk mencari variabel yang paling dominan mempengaruhii kompetensi mahasiswa adalah menggunakan persamaan regresi ganda $Y=9,463+0,759 X_{1}+0,819 X_{2}+0,763$ $\mathrm{X}_{3}$ koefisien praktik persekolahan sebesar 0,759 , koefisien rencana pembelajaran sebesar 0,819 dan koefisien pelaksanaan pembelajaran sebesar 0,763 sehingga dapat disimpulkan bahwa variabel yang paling dominan mempengaruhi kompetensi maahsiswa adalah variabel rencana pembelajaran.

\section{SIMPULAN DAN SARAN}

\section{Simpulan}

Berdasarkan hasil analisis data pelaksanaan praktik pengalaman lapangan dan dampaknya terhadap kompetensi mahasiswa prodi TIK STKIP PGRI Pontianak baik secara parsial maupun secara simultan, maka diperoleh kesimpulan sebagai berikut:

Distribusi skor kompetensi pedagogik mahasiswa yang melakukan PPL memiliki kecenderungan dalam kategori cukup dengan rata-rata nilai 3,30, kompetensi kepribadian memiliki kecenderungan dalam kategori cukup dengan rata-rata nilai 3,36, kompetensi sosial memiliki kecenderungan dalam kategori cukup dengan rata-rata nilai 3,40, kompetensi kepribadian kecenderungan dalam kategori baik dengan rata-rata nilai 3,42. Praktik persekolahan berpengaruh positif dan signifikan terhadap kompetensi mahasiswa sebagai calon guru ditunjukan dengan nilai $\mathrm{R}^{2}=0,515 ; \mathrm{p}=0,000$. Rencana Pembelajaran berpengaruh positif dan signifikan terhadap kompetensi mahasiswa sebagai calon guru ditunjukan dengan nilai $\mathrm{R}^{2}=0,272 ; \mathrm{p}=0,000$. Pelaksanaan Pembelajaran berpengaruh positif dan signifikan terhadap kompetensi mahasiswa sebagai calon guru ditunjukan dengan nilai $\mathrm{R}^{2}=$ 0,515; $\mathrm{p}=0,000$.Praktik persekolahan, Rencana Pembelajaran, Pelaksanaan Pembelajaran secara bersama-sama berpengaruh positif dan signifikan terhadap kompetensi mahasiswa sebagai calon guru dengan persamaan regresi $\mathrm{Y}=9,463+0,759 \mathrm{X}_{1}+0,819 \mathrm{X}_{2}+0,763 \mathrm{X}_{3}$. Nilai $\mathrm{R}^{2}$ regresi linier berganda sebesar 0,931 . Hal ini berarti ketiga variabel independen, yaitu Praktik persekolahan, Rencana Pembelajaran, Pelaksanaan Pembelajaran mampu menjelaskan perubahan variabel dependen kompetensi mahasiswa sebesar $93,1 \%$ sisanya $6,9 \%$ dijelaskan oleh faktor lain selain linier berganda.

\section{Saran}

Berdasarkan hasil penelitian dan kesimpulan yang telah dipaparkan, maka saran yang dapat disampaikan oleh peneliti sebagai berikut : Melihat kompetensi mahasiswa yang sedang melaksanakan kegiatan PPL termasuk dalam kategori baik, maka pihak STKIP PGRI Pontianak berperan meningkatkan mutu dan kompetensi mahasiswa yang akan melaksankan kegiatan PPL di tahun berikutnya agar menjadi lebih baik lagi. Seperti penguatan dalam kurikulum dengan mengintensifkan pembelajaran micro teaching dan mengadakan pendidikan karakter. Berdasarkan hasil penelitian yang menunjukan adanya pengaruh yang positif dan signifikan antara praktik persekolahan terhadap kompetensi mahasiswa prodi TIK STKIP PGRI Pontianak, maka diharapkan mahasiswa dapat meningkatkan praktik persekolahan. Berdasarkan hasil penelitian yang menunjukan adanya pengaruh yang positif dan signifikan antara rencana pembelajaran terhadap kompetensi mahasiswa prodi TIK STKIP PGRI Pontianak, maka diharapkan mahasiswa dapat meningkatkan 
rencana pembelajaran dengan cara membuat RPP dengan baik. Berdasarkan hasil penelitian yang menunjukan adanya pengaruh yang positif dan signifikan antara pelaksanaan pembelajaran terhadap kompetensi mahasiswa prodi TIK STKIP PGRI Pontianak, maka diharapkan mahasiswa dapat meningkatkan pelaksanaan pembelajaran dengan cara membuat pembelajaran yang efektif. STKIP PGRI Pontianak sebagai penyelenggara PPL hendaknya melakukan monitoring secara rutin kepada mahasiswa di sekolah-sekolah tempat pelaksanaan PPL. Monitoring tersebut mencakup memberi saran dan motivasi agar mahasiswa menjadi lebih baik dalam pelaksanaan PPL.

\section{DAFTAR PUSTAKA}

Admiral, Wilfried., et.al (2007). Supporting The Development Of Social Competencces Of Teachers Throught Computer Supported Collaborative Learning. Learning Throught DigitalTechnologies, 59-69 BJEP Monograph Series II. 5.

Barbazettte (2005). The trainer's journey to competence. San Francisco: preiffer.

Creswell (2006). Research design- qualitative, quantitative, and mixed method approache. Thousand Oaks: Sage Publication

Djohar. (2006). Guru, Pendidikan dan Pembinaannya: Penerapannya Dalam Pendidikan dan UU guru. Yogyakarta: CV. Gravika Indah.
Furchan, A. (2011). Pengantar Penelitian Dalam Pendidikan. Yogyakarta: PT. Pustaka Belajar.

Hartoyo.(1999). Kemampuan mengajar praktik guru sekolah menengah kejuruan negeri (SMKN) jurusan listrik di kotamadya Yogyakarta.Tesis.PPS UNY.

Joyce, Bruce.,\& Weil, Marsha. (1996). Models of teaching. $\left(5^{\text {th }}\right)$. Boston: Allyn\& Bacon.

Moh. Uzer Usman. (2009). Menjadi Guru Profesional. Bandung: PT. Remaja Rosdakarya.

Muhabbin Syah. (2010). Psikologi Pendidikan dengan Pendekatan Baru. Bandung: PT. Remaja Rosdakarya.

Roe R. A(2001). Definition and assessment of competences. Diambil pada 20 Juni 2011,dari http://arno.unimaas.nl/show. cgi?fid=14679

Roger, H., Hugh, G., Barry, H., et al. (1995). Competency-based education and training: Between a rock and whirlpool. Australia: Macmillan Education Australia PTY, LTD.

Sumadi Suryabrata (1999).Pengembangan alat ukur Psikologis. Jakarta :Drijen dikti depdikbud.

Wibowo. (2007). Manajemen Kinerja. Jakarta: Rajawali Pers. 